\title{
Impact of lambda-cyhalothrin on a macroinvertebrate assemblage in outdoor experimental channels: Implications for ecosystem functioning
}

\author{
Jes Jessen Rasmussen ${ }^{\mathrm{a}, \mathrm{c}}$, Nikolai Friberg ${ }^{\mathrm{b}, *}$, Soren E. Larsen ${ }^{\mathrm{c}}$ \\ a University of Aarhus, Department of Biological Sciences, Ole Worms Allé, Building 1135, 8000 Aarhus C, Denmark \\ ${ }^{\mathrm{b}}$ Macaulay Land Use Research Institute, Catchment Management Group, Craigiebuckler, Aberdeen AB15 8QH, UK \\ c University of Aarhus, National Environmental Research Institute, Department of Freshwater Ecology, Vejlsøvej 25, DK-8600 Silkeborg, Denmark
}

\section{A R T I C L E I N F O}

\section{Article history:}

Received 24 July 2008

Received in revised form 29 August 2008

Accepted 4 September 2008

\section{Keywords:}

Stream macroinvertebrates

Pyrethroids

Drift

Ecosystem function

Functional feeding groups

\begin{abstract}
A B S T R A C T
In this study, the impact of a single pulse of the pyrethroid lambda-cyhalothrin was tested on a macroinvertebrate assemblage consisting of Gammarus pulex, Leuctra nigra, Heptagenia sulphurea and Ancylus fluviatilis in outdoor experimental stream channels. Channels ( $4 \mathrm{~m}$ long, $0.1 \mathrm{~m}$ wide) were groundwater fed and had natural substratum. Macroinvertebrates were exposed to 10.65 or $106.5 \mathrm{ng} \mathrm{L}^{-1}$ lambda cyhalothrin for $90 \mathrm{~min}$ in the laboratory and after $24 \mathrm{~h}$ introduced to the experimental stream channels with four replicates of each treatment and controls. Drift samples were taken with 24-h interval for 10 days and behaviour of drifted macroinvertebrates was assessed. Microalgae biomass was measured on days 1, 5, 8 and 10 along with leaf litter decomposition using leaf packs of beech (Fagus sylvatica). Numbers of drifting G. pulex and L. nigra with reduced mobility increased significantly with concentration of lambda-cyhalothrin. Increase of algal biomass was significantly greater in stream channels with macroinvertebrates exposed to $106.5 \mathrm{ng} \mathrm{L}^{-1}$ compared to controls and $10.65 \mathrm{ng} \mathrm{L}^{-1}$ treatments. Accrual of microalgal biomass was significantly higher in the high concentration treatment and decomposition of leaf litter was significantly greater in control channels compared to channels with exposed macroinvertebrates. This study may apply valuable knowledge to the understanding and assessment of how pyrethroids impact ecosystem functioning in streams.
\end{abstract}

(c) 2008 Elsevier B.V. All rights reserved.

\section{Introduction}

Pesticides have a wide range of impacts on the aquatic biota (Larson et al., 1997) and in streams direct impacts have been found at all trophic levels ranging from algae to fish (Davies and Cook, 1993; Kreutzweiser et al., 1995; Guasch et al., 1997). Pesticides are widely used in crop protection and are transported to streams by a range of different routes including wind drift, run-off or point sources (Hill et al., 1994). The major contributor to pesticide contamination is reported by several studies to be drainage water/sub-surface run-off, which strongly coincides with high levels of precipitation (Mathiessen et al., 1995; Liess and Schulz, 1999; Schulz and Liess, 1999a). Both dissolved and particle bound pesticides are transported from the soil surface or subsurface to stream recipients (Schulz et al., 1998) with pesticides having low water solubility (e.g. pyrethroids) generally dissipating very rapidly from the dissolved phase (Schroer et al., 2003). Depending on different physical and chemical characteristics of the receiving stream as well as

\footnotetext{
* Corresponding author. Tel.: +44 1224498200.

E-mail address: n.friberg@macaulay.ac.uk (N. Friberg).
}

physical and chemical properties of pesticides, both particle-bound and dissolved pesticides give rise to short $(1-2 \mathrm{~h})$ pulses of acute contamination followed by series of smaller pulses during the subsequent $24 \mathrm{~h}$ (Liess et al., 1999; Kronvang et al., 2004). In contrast, pesticides bound to the sediment can be retained in the stream ecosystem for longer periods (weeks to months) after the actual exposure incident has occurred (Kronvang et al., 2003; Friberg et al., 2003).

In Denmark $62 \%$ of the total area $\left(43,000 \mathrm{~km}^{2}\right)$ is used as agricultural land. Total length of natural and artificial streams is $60,000 \mathrm{~km}$, the majority of which are small in size ( $<2 \mathrm{~m}$ wide). In Denmark approximately $80 \%$ of the total agricultural land is sprayed with pyrethroids (Danish Environmental Protection Agency, 2003). The combination of extensive use of pyrethroids and the close connectivity between land and stream, enhanced artificially by drainage and narrow buffer strips, makes the potential risk of pyrethroid exposure extremely high (Friberg et al., 2003). Until now, only few records of detection of pyrethroids in the stream water phase exist, which is likely explained by the episodic nature of pesticide transport to streams, the rapid dissipation from the water phase and infrequent sampling (Lauridsen et al., 2006). Stream water concentrations of pyrethroids more than $0.1 \mu \mathrm{g} \mathrm{L}^{-1}$ were detected in 
$20 \%$ of the water samples collected in relation to high precipitation incidents in three Danish streams draining agricultural areas with up to $66 \mu \mathrm{g} \mathrm{L}^{-1}$ found on one occasion (Wiggers, 1999). Likewise, sediment samples in 30 Danish streams have revealed that the pyrethroid lambda-cyhalothrin was the most frequently found insecticide (7\%) and in concentrations up to $20 \mathrm{ng} \mathrm{g}^{-1}$ sediment (Kronvang et al., 2003; Friberg et al., 2003).

Pyrethroids primarily have an effect on the nervous system by decreasing the decay of the action potential (e.g. Clark and Matsumura, 1982; Narahashi et al., 1995). The toxicological impact of pyrethroids has been intensively tested in the laboratory and in field/mesocosm setups on various non-target species with stream macroinvertebrates attracting considerable attention as they respond strongly to pyrethroid exposure (e.g. Anderson, 1989; Schulz and Liess, 1999b). Many previous studies of the toxicological impact of pyrethroids on stream macroinvertebrates have used mortality, immobilization and offset of catastrophic drift as endpoints (e.g. Farmer et al., 1995; Schulz and Liess, 1999b; Heckmann and Friberg, 2004). Despite the brief episodic occurrence and low actual concentrations of pyrethroids in natural streams, the highly toxic nature of pyrethroids may produce long term effects not readily observable. Pyrethroid contamination has the potential to produce fundamental impacts on ecosystem structure, function and biotic interactions due to a combination of direct and indirect effects (Schulz and Liess, 1999b). Leaf litter breakdown rates are frequently used proxies for ecosystem function (Gessner and Chauvet, 2002) and have been shown to decrease with elevated concentrations of pesticides in the field (Schäfer et al., 2007). A laboratory study has, furthermore, shown a reduction in the leaf shredding activity of the trichopteran Sericostoma personatum and the amphipod Gammarus pulex when exposed to lambda-cyhalothrin in environmentally realistic concentrations (Lauridsen et al., 2006). These findings indicate that pyrethroids may cause indirect effects in more complex experimental systems or natural streams, and could potentially impair ecosystem functioning.

The aim of the present study was to investigate in outdoor experimental channels: (1) direct effects of lambda-cyhalothrin on mortality, drift and behaviour on a macroinvertebrates assemblage, representing different life histories and feeding functionalities, and relate these effects to (2) proxies of ecosystem function represented by accrual of microalgal biomass (grazing pressure) and decomposition rates of leaf litter (shredder activity).

\section{Materials and methods}

\subsection{Channel setup}

The experiment was conducted in an outdoor stream channel facility in Lemming, Denmark $\left(9^{\circ} 40^{\prime}, 56^{\circ} 15^{\prime}\right)$ and carried out in April 2005. The setup consisted of 12 replicated stream channels, which were constantly supplied with groundwater. Using groundwater instead of surface water has the advantage of reducing risks of contamination and a constant chemical composition over time. Chemical properties of the water used were typical for Denmark with fairly high levels of nitrogen but low concentrations of phosphorous (Table 1). The water was oxidized before being led through a distribution box which supplied 12 experiment channels with equal amounts of water (Table 1 ). The stream channels were $4 \mathrm{~m}$ long and $0.1 \mathrm{~m}$ wide with a slope of $1 \%$, which is comparable to a riffle section in a small Danish stream. Prior to the experiment they were stocked with coarse gravel/small pebbles $(1-3 \mathrm{~cm}$ in diameter) that had been conditioned in nutrient enriched water to allow establishment of a dense biofilm. Seven cobbles $(10-15 \mathrm{~cm})$ were equally spaced in each channel to increase retention and create suitable habitats. Mean water residence time was $52 \mathrm{~s}$ and mean
Table 1

Chemical and physical parameters for stream channel water

\begin{tabular}{lc}
\hline Chemical parameters & Value/concentration \\
\hline $\mathrm{NH}_{4}\left(\mathrm{mg} \mathrm{L}^{-1}\right)$ & 0.009 \\
$\mathrm{NO}_{2}+\mathrm{NO}_{3}\left(\mathrm{mg} \mathrm{L}^{-1}\right)$ & 2.720 \\
$\left.\mathrm{Total} \mathrm{N} \mathrm{mg} \mathrm{L}^{-1}\right)$ & 2.830 \\
$\mathrm{PO}_{4}\left(\mathrm{mg} \mathrm{L}^{-1}\right)$ & 0.003 \\
$\mathrm{Total}_{\mathrm{P}\left(\mathrm{mg} \mathrm{L}^{-1}\right)}$ & 0.003 \\
Total Fe $\left(\mathrm{mg} \mathrm{L}^{-1}\right)$ & 0.005 \\
$\mathrm{pH}$ & 7.0 \\
& \\
Physical parameters & 3.5 \\
Discharge per stream channel $\left(\mathrm{Lmin}{ }^{-1}\right)$ & $51.6 \pm 2.7$ \\
Mean water resident time per stream channel (s) & $0.0679 \pm 0.003$ \\
Mean water velocity $\left(\mathrm{m} \mathrm{s}^{-1}\right)$ & $6.48-7.96$ \\
Water temperature $(\mathrm{range})\left({ }^{\circ} \mathrm{C}\right)$ & \\
\hline
\end{tabular}

water velocity $0.07 \mathrm{~m} \mathrm{~s}^{-1}$ which would be typical for low flow conditions in small streams (Table 1). A Stowaway Tidbit temperature logger was positioned in the downstream end of the substratum sections, and temperature fluctuation was measured for $24 \mathrm{~h}$ (Table 1).

\subsection{Macroinvertebrate assemblage}

The macroinvertebrate assemblage used was composed of four species: Gammarus pulex (amphipod), Leuctra nigra (stonefly), Heptagenia sulphurea (mayfly) and Ancylus fluviatilis (gastropod). Selection of these macroinvertebrates was based on a series of criteria. They represent some of the most dominant taxonomic groups of macroinvertebrates in Denmark (Dall and Lindegaard, 1995). They differ in life history and feeding functionality encompassing scrapers of algae and biofilm (Heptagenia, Ancylus), shredders of leaf materials (Gammarus, Leuctra) and predators of other macroinvertebrates (Gammarus) (Møhlenberg et al., 2004). Individuals used for experimentation were collected at local stream sites immediately (days) before being exposed.

\subsection{Pesticide and exposure}

Applied concentrations of lambda-cyhalothrin were selected based on peak concentrations of pyrethroids found in water samples from Danish agricultural streams during high flow events (Wiggers, 1999 in Introduction). A dilution series was produced in ethanol (96\%) to achieve intended concentrations of lambdacyhalothrin. Exposure was conducted in plastic containers with $10 \mathrm{~L}$ groundwater. Lambda-cyhalothrin was applied in $5 \mathrm{ml}$ ethanol in all exposure containers. $5 \mathrm{~mL}$ ethanol was applied in control containers as well. Macroinvertebrates were introduced to exposure and control containers (lightly aerated at $4{ }^{\circ} \mathrm{C}$ ) immediately after application of ethanol (controls) or the lambda-cyhalothrin solution (exposure). Intended concentrations of lambda-cyhalothrin were $10.65 \mathrm{ng} \mathrm{L}^{-1}$ and $106.5 \mathrm{ng} \mathrm{L}^{-1}(n=4)$ and the exposure period was $90 \mathrm{~min}$. Water from exposure containers was collected immediately after the exposure period and analyzed for actual concentrations of lambda-cyhalothrin. The basic principle of the applied method used to quantify lambda-cyhalothrin concentrations is based on solid phase extraction followed by solution concentration in the process of evaporation and quantification using reverse phase HPLC-MS (Nørum et al., 2006). Actual exposure concentrations were $92 \mathrm{ng} \mathrm{L}^{-1}$ for the $106.5 \mathrm{ng} \mathrm{L}^{-1}$ treatment while concentrations were below detection limit $\left(10 \mathrm{ng} \mathrm{L}^{-1}\right)$ in the $10.65 \mathrm{ng} \mathrm{L}^{-1}$ treatment. After exposure, macroinvertebrates were transferred to aerated plastic containers with uncontaminated groundwater $\left(4{ }^{\circ} \mathrm{C}\right)$ for $24 \mathrm{~h}$ with access to food (leaf litter and pebbles with biofilm). After this period macroinvertebrates were transported to 
the outdoor research facility and distributed to channels. Initial species numbers in each channel for G. pulex, L. nigra, H. sulphurea, A. fluviatilis were $65,45,16$ and 25 , corresponding to the densities of $433,300,107$ and 167 individuals $\mathrm{m}^{-2}$, respectively. Each treatment group (control, 10.65 and $106.5 \mathrm{ng} \mathrm{L}^{-1}$ ) was replicated in four stream channels.

\subsection{Macroinvertebrates in drift}

Macroinvertebrates were monitored in the stream channels for 10 consecutive days. At the end of each channel a net (mesh size $0.5 \mathrm{~mm}$ ) was mounted to collect drift samples and nets were emptied every day at $10 \mathrm{a} . \mathrm{m}$. in the experimental period. All macroinvertebrates caught were counted and their behaviour was assessed using three categories: normal activity (preserved escape response by physical touch), reduced activity (restricted escape response by physical touch) and dead. All macroinvertebrates alive were reintroduced into the respective stream channels. At the end of the experiment, all remaining substratum was preserved in $96 \%$ ethanol and later sorted for macroinvertebrates.

\subsection{Microalgae accrual and leaf litter decomposition}

Increase of algal biomass reflects grazing activity of macroinvertebrates in this simplified community. In this study we used chlorophyll a density as a measure for algal coverage of the substratum. The gravel/pebble substrate was collected from each channel on experimental days 1 (prior to the introduction of macroinvertebrates) 5, 8 and 10 for chlorophyll a analysis. Chlorophyll was extracted in ethanol and the absorbance at $665 \mathrm{~nm}$ was measured in a PharmaSpec UV-1700 spectrophotometer. Total chlorophyll a was calculated from the projected area of each collected gravel/pebble.

Leaf pack weight loss reflects shredding activity and as such is a measure for decomposition of coarse particulate organic material (CPOM). Five leaf packs were placed evenly spaced upstream of cobbles to secure that they would keep position. Each leaf pack was constituted of 10 conditioned beech leaves (Fagus sylvatica) collected from a small groundwater fed first order stream in Velling Forest, Denmark. The catchment for this stream is entirely old beech forest, thus the collected leaves have not been exposed to environmental toxins prior to the experiment. Initial dry weight (DW) was established by drying 15 randomly selected beech leaves to a constant weight at $60^{\circ} \mathrm{C}$ and then weighing on a Mettler Toledo XP204 balance with three decimals accuracy. After the last emptying of driftnets on day 10, all leaf packs were retrieved and macroinvertebrates were removed and preserved in $96 \%$ ethanol. Final DW of each leaf pack was established using the procedure described above.

\subsection{Macroinvertebrate size estimations}

The size of different morphological parts was measured on all macroinvertebrates and DW was calculated using established relationships between the size of a morphological measure (e.g. the width of head capsules) and their DW (Zelinka and Marvan, 1976; Iversen and Jessen, 1977; Friberg et al., 2002). For A. fluviatilis it was necessary to establish a new length/DW relationship by collecting additional individuals in the field and measuring length of shells followed by individual DW estimation. For all species DW was estimated using simple linear regression and was $4.45 \pm 0.10 \mathrm{mg}$ for $G$. pulex, $0.29 \pm 0.007 \mathrm{mg}$ for $L$. nigra, $1.64 \pm 0.07 \mathrm{mg}$ for $H$. sulphurea and $4.35 \pm 0.25 \mathrm{mg}$ for A. fluviatilis.

\subsection{Statistics}

The primary analytical approach of drift, macroinvertebrate activity, microalgae accrual and leaf litter decomposition data were ANOVA and repeated measures ANOVA since response variables were observed over time (Littell et al., 1996). Specifically, drift data were analysed by a repeated mixed effect model (Littell et al., 1996) with pesticide treatment as fixed effect, channels as a random effect and day as repeated measure. The variance structure was modelled by a compound symmetry variance matrix. Pairwise tests were done by least square means and $t$-tests (SAS Institute Inc., 1989). The analysis of algae was done using exactly the same methods as for the drift data, but the variance structure was modelled by an unstructured variance matrix. The leaf pack data was analyzed by a mixed effect model with pesticide treatment as fixed effect and channels as random effect. Pairwise tests were done by least square means and $t$-tests.

\section{Results}

\subsection{Channel macroinvertbrate numbers}

The number of macroinvertebrates did not decline significantly $(P>0.05)$ during the experimental period in any treatment group or channel as mortality was low and all individuals alive caught in drift were reintroduced. Average total number of $G$. pulex ranged from 61 individuals in $106.5 \mathrm{ng} \mathrm{L}^{-1}$ treatment to 63 individuals in controls, from 42 (106.5 $\mathrm{ng} \mathrm{L}^{-1}$ treatment) to 44 (controls) for L. nigra, from 14 (106.5 $\mathrm{ng} \mathrm{L}^{-1}$ treatment) to 15 (controls) for $H$. sulphurea and with $A$. fluvialtilis numbers being constant at 25 indivduals across treatments and controls.

\subsection{Macroinvertebrate drift}

The proportion of G. pulex in drift increased for all groups (control, 10.65 and $106.5 \mathrm{ng} \mathrm{L}^{-1}$ ) after 4 days reaching a plateau for the remaining part of the experimental period (Fig. 1a). Drift in control channels was significantly higher than both treatment groups ( $t=9.54, P<0.0001$ and $t=16.70, P<0.0001$, respectively). Between treatment groups drift was significantly higher in channels with macroinvertebrates exposed to $10.65 \mathrm{ng} \mathrm{L}^{-1}$ compared with $106.5 \mathrm{ng} \mathrm{L}^{-1}(t=7.16, P<0.0001)$.

As for G. pulex drift of L. nigra increased after 4 days but no consistent trend was evident in drift pattern among the three groups (Fig. 1b). Only few H. sulphurea drifted and there were no significant differences in drift pattern between treatment groups (data not shown). No A. fluviatilis drifted in the experimental period.

\subsection{Activity of macroinvertebrates}

The proportion of G. pulex that maintained a normal activity level decreased with the concentration of lambda-cyhalothrin (Fig. 2a) which in $106.5 \mathrm{ng} \mathrm{L}^{-1}$ treatment corresponded to $3 \%$ of the total number of individuals. The number of G. pulex individuals showing reduced mobility increased slightly with concentration of lambda-cyhalothrin. Compared to controls, the proportion of $G$. pulex with normal activity level was significantly lower in both treatments $(t=8.46, P<0.0001$ and $t=15.68, P<0.0001$, respectively). Between treatments the proportion of individuals with normal activity level was significantly lower in the $106.5 \mathrm{ng} \mathrm{L}^{-1}$ treatment compared to $10.65 \mathrm{ng} \mathrm{L}^{-1}(t=7.22, P<0.0001)$. Activity level of $G$. pulex was significantly reduced in treatment channels $\left(F_{9,81}=20.21, P<0.0001\right)$ and with significant interaction between time and concentration $\left(F_{18,81}=7.11, P<0.0001\right)$ (data not shown) 

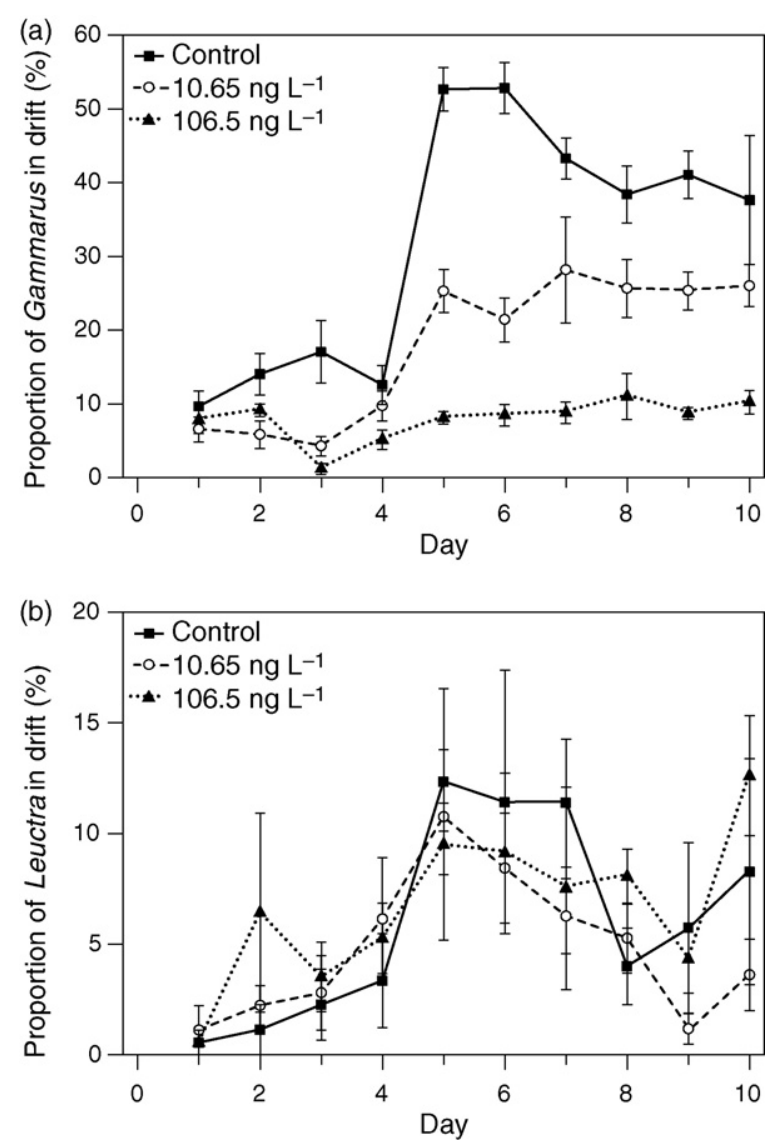

Fig. 1. The average proportion of G. pulex (a) and L. nigra (b) in drift during the experimental period (10 days) \pm S.E. in stream channels with individuals treated with 0 (control), 10.65 and $106.5 \mathrm{ng} \mathrm{L}^{-1}$ lambda-cyhalothrin. Each treatment and control with four replicates.

with the proportion of $G$. pulex with reduced mobility significantly increasing through the experimental period $\left(F_{9,81}=3.26\right.$, $P=0.0020)$.

The proportion of L. nigra in drift with normal activity declined with treatments while the proportion of individuals showing reduced mobility increased (Fig. 2b). The proportion of individuals with reduced activity level was significantly lower in the $106.5 \mathrm{ng} \mathrm{L}^{-1}$ treatment compared to controls $(t=-4.14, P=0.0025)$ and the $10.65 \mathrm{ng} \mathrm{L}^{-1}$ treatment $(t=-2.54, P=0.0317)$. There was a significant interaction between time and concentration for activity level $\left(F_{18,81}=1.99, P=0.019\right)$ (data not shown).

Despite that only few $\mathrm{H}$. sulphurea were observed in drift, activity level in the $106.5 \mathrm{ng} \mathrm{L}^{-1}$ treatments was reduced compared to the $10.65 \mathrm{ng} \mathrm{L}^{-1}$ treatments and controls (Fig. 2c). The proportion of individuals with normal activity was significantly different between groups of treatment. $\left(F_{2,9}=5.73, P=0.024\right)$, and there was a significant effect of the time of sampling $\left(F_{9,81}=2.22, P=0.029\right)$. No A. fluviatilis was found in drift during the experiment (data not shown).

\subsection{Microalgal biomass accrual}

Algal biomass increased during the experimental period in all groups. There was a significant effect of treatment and time of sampling on algal biomass $\left(F_{2,9}=5,09, P=0.033\right.$ and $F_{2,9}=8,46$, $P=0,0086$, respectively). Treatment with $106.5 \mathrm{ng} \mathrm{L}^{-1}$ lambdacyhalothrin had a strong effect on the grazers' ability to reduce algal biomass. Average initial chlorophyll a density was $3.57 \mathrm{mg} \mathrm{m}^{-2}$. In channels with macroinvertebrates exposed to $106.5 \mathrm{ng} \mathrm{L}^{-1}$ lambdacyhalothrin chlorophyll a density increased to $16.15 \mathrm{mg} \mathrm{m}^{-2}$, while the increment during the 10-day experimental period chlorophyll a merely increased to 6.25 and $4.30 \mathrm{mg} \mathrm{m}^{-2}$ in $10.65 \mathrm{ng} \mathrm{L}^{-1}$ treatment and controls, respectively (Fig. 3). Algal biomass was significantly higher in channels with macroinvertebrates exposed to $106.5 \mathrm{ng} \mathrm{L}^{-1}$ compared to the $10.65 \mathrm{ng} \mathrm{L}^{-1}$ treatment and controls $(t=-2.49, P=0.035$ and $t=-2.98, P=0.016$, respectively). The increase of algal biomass in the $10.65 \mathrm{ng} \mathrm{L}^{-1}$ treatments was not significantly greater than in control channels.

\subsection{Leaf litter decomposition}

Total decomposition of leaf packs was significantly higher in control channels compared to channels with treated macroinvertebrates $(t=-2.98, P=0.016$ and $t=-2.49, P=0.035)$. Leaf pack weight loss was $0.17 \mathrm{~g}$ DW in control channels, three times greater than 0.05 and $0.06 \mathrm{~g} \mathrm{DW}$ in 10.65 and $106.5 \mathrm{ng} \mathrm{L}^{-1}$ treatments, respectively (Fig. 4). The difference in leaf pack weight loss between the two treated groups was not significant $(P>0.05)$.

\section{Discussion}

Effects of pesticide contamination on community and ecosystem level in streams have previously been observed at environmentally realistic concentration levels (e.g. Wallace et al., 1989; Sibley et al., 1991; Schulz and Liess, 1999b). Other more recent studies have found various indirect effects of pesticide exposure in addition to the more frequently used end points such as mortality or exclusion of species (Lauridsen et al., 2006; Nørum et al., 2006; Schäfer et al., 2007). In this study several species were allowed to interact in a seminatural system and the results support previous findings of direct and indirect effects of pyrethroids on macroinvertebrates in running waters. Density of species in the mesocosm remained approximately constant during the experiment because of the reintroduction of all living individuals caught in drift. Thus differences in leaf decomposition rate and algal grazing activity cannot be attributed to decreasing species densities according to loss of macroinvertebrates from the stream channels.

During the 10-day experimental period, only G. pulex significantly changed drift pattern compared to the control group. Drift significantly decreased with lambda-cyhalothrin concentration, while there were no significant changes in drift activity between treatment groups for L. nigra, H. sulphurea and A. fluviatilis. An increase in drift rate for G. pulex in controls and $10.65 \mathrm{ng} \mathrm{L}^{-1}$ treatments and for $L$. nigra in all treatments was observed on day 5 . No significant external disturbance could explain this change but it might reflect a change in weather to more overcast conditions promoting drift activity in general (see e.g. Allan, 1995). The initially lower drift activity for both G. pulex and L. nigra and the subsequent higher but stable activity level for G. pulex might indicate an acclimation period after their introduction into the channels. Previous studies have shown that the primary response of $G$. pulex and other macroinvertebrates is to enter catastrophic drift when exposed to pyrethroids (e.g. Muirhead-Thomsen, 1978; Davies and Cook, 1993; Heckmann and Friberg, 2004; Nørum et al., 2006). The observed decrease in post exposure drift rate in G. pulex with pesticide treatment might be ascribed to a reduction in activity level that make them less prone to enter drift. These findings are in accordance with previous video tracking recovery studies (Nørum et al., 2006), where G. pulex was exposed to $100 \mathrm{ng} \mathrm{L}^{-1}$ lambda-cyhalothrin for 4.5 h. G. pulex here showed reduced mobility in a subsequent period of 1-3 days, and mortality increased in the entire recovery period of 21 days. 

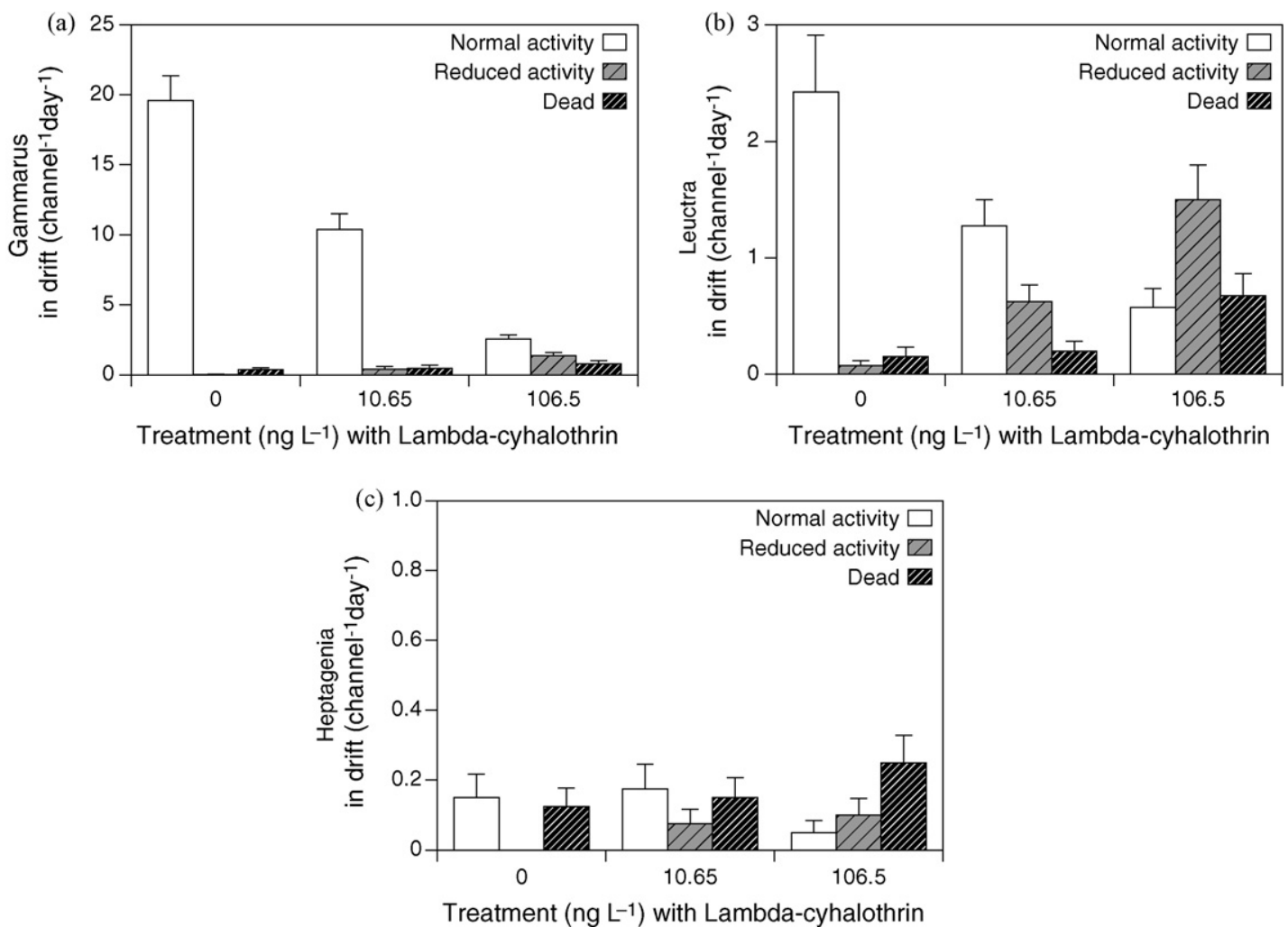

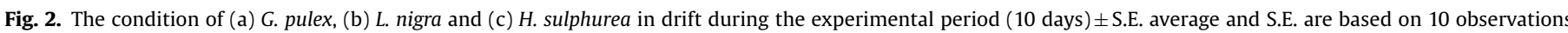

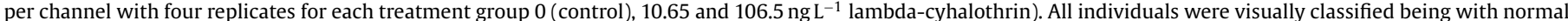
activity (preserved escape response by physical touch), reduced activity (restricted escape response by physical touch) and dead.

According to functional grouping of the four macroinvertebrate species in the mesocosm community, A. fluviatilis is the most significant and efficient grazer followed by H. sulphurea (Elliott et al., 1988; Dall and Lindegaard, 1995). However, both G. pulex and $L$. nigra can feed on benthic algae if the resource is readily accessible (Marchant, 1981; Henderson et al., 1990).

The significant increase in total algal biomass in stream channels with macroinvertebrates treated with $106.5 \mathrm{ng} \mathrm{L}^{-1}$ compared with control and the $10.65 \mathrm{ng} \mathrm{L}^{-1}$ treatment might indicate that the ability of the macroinvertebrate assemblage to regulate total algal biomass was altered. In accordance to this Kjeldsen (1996) found that algal biomass on rocks frequently rinsed with the pyrethroid

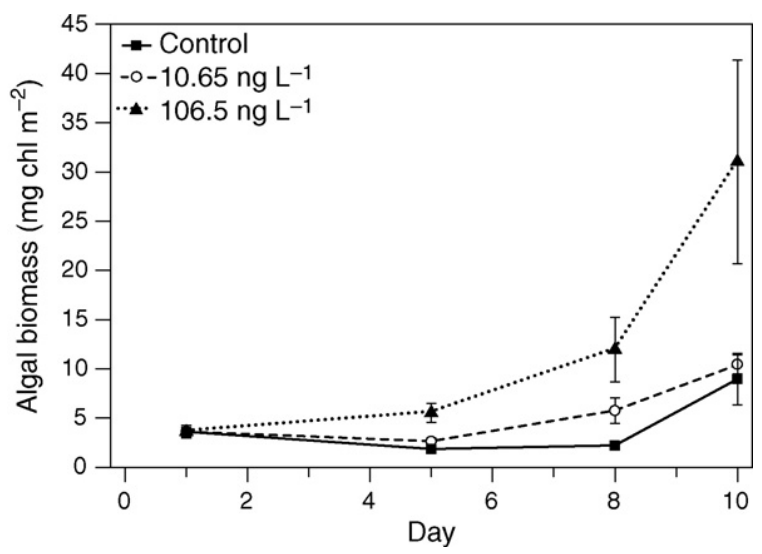

Fig. 3. Changes of algal biomass during the experimental period ( 10 days). Gravel used for chlorophyll a analyses was gathered on day 5, 8 and 10 and for reference on day 1 . Each mark represents average \pm S.E. for each treatment group ( 0 (control), 10.65 and $106.5 \mathrm{ng} \mathrm{L}^{-1}$ lambda-cyhalothrin). permethrin was higher than that of rocks rinsed with water, caused by a release of macroinvertebrate grazing pressure. Our setup did not directly allow us to assess how feeding activity of each individual species was affected by the exposure. However, considering that neither drift activity nor behaviour of $A$. fluviatilis appeared to be altered in any way and the reported low sensitivity of molluscs to pyrethroids (Schroer et al., 2003), it is unlikely that this species was responsible for the change in grazing pressure. With regard to H. sulphurea too few individuals were caught in drift and assessed to establish if this species was affected by the treatment to a degree that would impact feeding efficiency. In contrast, both G. pulex and L. nigra were clearly affected and it seems likely that these two

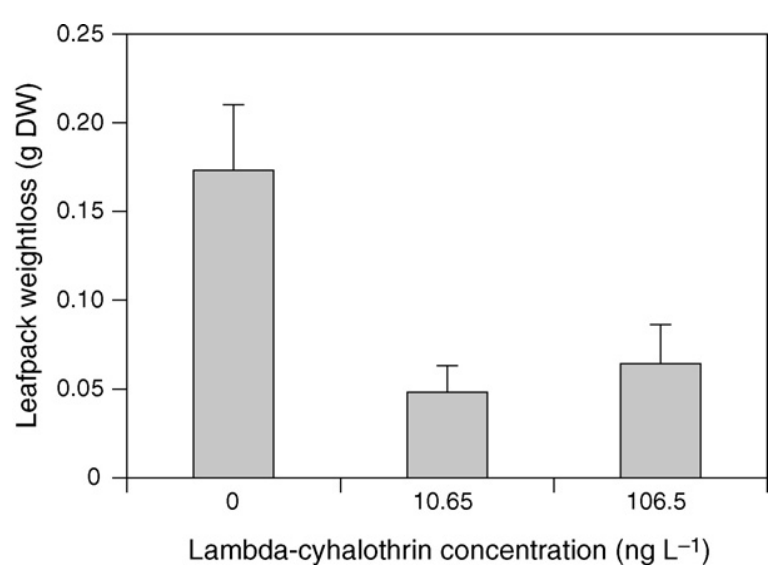

Fig. 4. Weight loss (g DW) in leaf packs during the experimental period (10 days $) \pm$ S.E. average and S.E. are based on 5 leaf packs per streamchannel with four replicates for each treatment group $\left(0,10.65\right.$ and $106.5 \mathrm{ng} \mathrm{L}^{-1}$ lambda-cyhalothrin). 
species were primarily responsible for changes in grazing pressure, indicating that they might be more efficient grazers of microalgae than normally believed.

In this study treatment with lambda-cyhalothrin had a pronounced effect on macroinvertebrate shredding activity. Decomposition of leaf packs was significantly lower in channels with treated macroinvertebrates compared to controls but there were no clear dose-response effect. G. pulex and L. nigra dominated the community in number and density. Both species act primarily as shredders and feed upon CPOM in natural ecosystems (Iversen, 1988). The activity of individuals of both species in drift was reduced in both 10.65 and $106.5 \mathrm{ng} \mathrm{L}^{-1}$ treatments though the assessed condition of $L$. nigra was based on relatively few numbers. These results are supported by other studies using video tracking which have revealed long term reduction of mobility in G. pulex after exposure to $10 \mathrm{ng} \mathrm{L}^{-1}$ lambda-cyhalothrin, cypermethrin or esfenvalerate in the laboratory (Nørum and Bjerregaard, 2003; Nørum et al., 2006).

Our findings suggest that G. pulex and L. nigra are highly sensitive to this pyrethroid and that effects can be seen not only in form of readily induced short-term behavioural changes such as hypermobility, but also as longer term effects with subsequent reduced mobility and possibly feeding activity. This contention is supported by Møhlenberg et al. (2004) who found reductions in shredding activity for G. pulex exposed to $0.02 \mu \mathrm{g} \mathrm{L}^{-1}$ esfenvalerate for $30 \mathrm{~min}$. Furthermore L. nigra and G. pulex are the two most sensitive species towards pyrethroids in this simplified macroinvertebrate community (e.g. Anderson and Shubat, 1984; Giddings et al., 2001; Schroer et al., 2003). The lack of a clear dose-response correlation regarding shredding activity between the 10.65 and $106.5 \mathrm{ng} \mathrm{L}^{-1}$ treatments could be explained by the relatively short experimental period. Nørum et al. (2006) studied predator-prey interactions between $G$. pulex and L. nigra impacted by lambda-cyhalothrin and found the strongest dose-response correlation between 1 and $10 \mathrm{ng} \mathrm{L}^{-1}$. Thus the observed effect of lambda-cyhalothrin concentration on shredding activity, and maybe grazing pressure as well, would possibly have been stronger with a longer experimental period.

The exposure scenario we used was mimicking a run-off event where pesticides recently applied, either dissolved or bound to particles, enters the stream ecosystem in periods with high precipitation. Several Danish studies have shown this scenario provides the highest peak concentrations with regard to pyretheroids and occurs more frequently under natural conditions than other routes of exposure such as spray drift (e.g. Wiggers, 1999; Kronvang et al., 2004).

A key question when utilising a mesocosm approach is to what extent these artificial environments mimic natural conditions, i.e. their realism. Limited biological complexity or scale-dependent behaviour of component species could limit the relevance and applicability to real systems (Cooper and Barmuta, 1993). We used concentrations of lambda-cyhalothrin in a range that have been observed in Danish streams (Wiggers, 1999) and exposed macroinvertebrates to a short 90 min pulse mimicking realistic exposure conditions under high run-off events. As we exposed macroinvertebrates in the laboratory without the combined of stress of increased water velocities that would occur under in-stream conditions, our experimental design might underestimate the negative impact of lambda-cyhalothrin on macroinvertebrates in real exposure scenarios. In contrast, we might have overestimated impacts on ecosystem function as there is likely to be a greater functional redundancy in natural systems compared with our simplified fourspecies assemblage. However, negative impacts of pyrethroids on both grazing and leaf litter processing has been reported from studies of natural streams (Kjeldsen, 1996; Schäfer et al., 2007) and our experiment clearly supports the hypothesis that lambdacyhalothrin potentially can change ecosystem function.

\section{Acknowledgements}

The authors gratefully acknowledge the support of the Danish Environmental Protection Agency, J Kristensen and T.K. Jensen for field assistance and U. Nørum for pesticide analyses. Moreover, we would like to thank T. Riis and A. Vinten for valuable comments on an earlier draft of the manuscript. N. Friberg was partly sponsored by the Scottish Executive Environment and Rural Affairs Department (WP3.4).

\section{References}

Allan, J.D., 1995. Stream Ecology. Chapman \& Hall, London.

Anderson, R.L., 1989. Toxicity of synthetic pyrethroids to freshwater invertebrates. Environ. Toxicol. Chem. 8, 403-410.

Anderson, R.L., Shubat, P., 1984. Toxicity of flucythrinate to Gammarus lacustris (Amphipoda), Pteronarcys dorsata (Plecoptera) and Brachycentrus americanus (Trichoptera)-importance of exposure duration. Environ. Pollut. A: Ecol. Biol. 35, 353-365.

Clark, J.M., Matsumura, F., 1982. Two different types of inhibitory effect of pyrethroids on nerve Ca- and $\mathrm{Mg}$ ATPase in the squid, Loligo paeli. Pestic. Biochem. Physiol. 4, 232-238.

Cooper, S.D., Barmuta, L.A., 1993. Field experiments in biomonitoring. In: Rosenberg, D.M., Resh, V.H. (Eds.), Freshwater Biomonitoring and Benthic Macroinvertebrates. Chapman \& Hall, London, pp. 341-399.

Dall, P., Lindegaard, C., 1995. A Review of Danish Freshwater Invertebrates for Assessment of Pollution in Lakes and Streams. Ferskvandsbiologisk Laboratorium, Københavns Universitet (in Danish).

Danish Environmental Protection Agency, 2003. Pesticide Statistics 2002. Danish Environmental Protection Agency, Orientering fra Miljøstyrelsen 5. Copenhagen, Denmark (in Danish).

Davies, P.E., Cook, L.S.J., 1993. Catastrophic macroinvertebrate drift and sublethal effects on brown trout, Salmo trutta, caused by cypermethrin spraying on a Tasmanian stream. Aquat. Toxicol. 27, 201-224.

Elliott, J.M., Humpesch, U.H., Macan, T.T., 1988. Larvae of the British Ephemeroptera: A Key with Ecological Notes. FBA Scientific Publication no. 49, Ambleside, Cumbria, UK.

Farmer, D., Hill, I.R., Maund, S.J., 1995. A comparison of the fate and effects of two pyrethroid insecticides (lambda-cyhalothrin and cypermethrin) in pond mesocosms. Ecotoxicology 4, 219-244.

Friberg, N., Larsen, A.D., Rodkjaer, A., Thomsen, A.G., 2002. Shredder guilds in three Danish forest streams contrasting in forest type. Arch. Hydrobiol. 153, 197-215.

Friberg, N., Lindstrøm, M., Kronvang, B., Larsen, S.E., 2003. Macroinvertebrate/sediment relationships along a pesticide gradient in Danish streams. Hydrobiologia 494, 103-110.

Gessner, M.O., Chauvet, E., 2002. A case for using litter breakdown to assess functional stream integrity. Ecol. Appl. 12, 498-510.

Giddings, J.M., Solomon, K.R., Maund, S.J., 2001. Probabilistic risk assessment of cotton pyrethroids: II. Aquatic mesocosm and field studies. Environ. Toxicol. Chem. 20, 660-668.

Guasch, H., Munoz, N., Roses, N., Sabater, S., 1997. Changes in atrazine toxicity throughout successions of stream periphyton communities. J. Appl. Phycol. 9, 137-146.

Heckmann, L.H., Friberg, N., 2004. Macroinvertebrate community response to pulse exposure with the insecticide lambda-cyhalothrin using in-stream mesocosms. Environ. Toxicol. Chem. 24, 582-590.

Henderson, J., Hildrew, A.G., Townsend, C.R., 1990. Detritivorous stoneflies in an ironrich stream: food and feeding. I: I.C. Campbell (red.) Mayflies and stoneflies. Kluwer Academic Publishers, Dordrecht, The Netherlands.

Hill, I.R., Travis, K.Z., Ekoniak, P., 1994. Spray drift and runoff simulations of foliarapplied pyrethroids to aquatic mesocosms: rates, frequencies and methods. In: Graney, R.L., Kennedy, J.H., Rodgers, J.H. (Eds.), Aquatic Mesocosm Studies in Ecological Risk Assessment. Lewis, Boca Raton, FL, USA, pp. 201-239.

Iversen, T.M., 1988. Secondary production and trophic relationships in a spring invertebrate community. Limnol. Oceanogr. 33, 582-592.

Iversen, T.M., Jessen, J., 1977. Life-cycle, drift and production of Gammarus pulex (L.) (Amphipoda) in a Danish spring. Freshwater Biol. 7, 287-296.

Kjeldsen, K., 1996. Regulation of algal biomass in a small lowland stream: field experiments on the role of invertebrate grazing, phosphorous and irradiance. Freshwater Biol. 36, 535-546.

Kreutzweiser, D.P., Capell, S.S., Sousa, B.C., 1995. Hexazione effects on stream periphyton and invertebrate communities. Environ. Toxicol. Chem. 14, 1521-1527.

Kronvang, B., Laubel, A., Larsen, S.E., Friberg, N., 2003. Pesticides and heavy metals in Danish streambed sediment. Hydrobiologia 494, 93-101.

Kronvang, B., Strøm, H.L., Hoffmann, C.C., Laubel, A., Friberg, N., 2004. Subsurface tile drainage loss of modern pesticides: field experiment results. Water Sci. Technol. 49, 139-148. 
Larson, D.J., Capel, P.D., Majewski, M.S., 1997. Pesticides in Surface Water: Distribution, Trends and Governing Factors. Pesticides in Hydrological Systems, vol. 3. Ann Arbor Press, Michigan.

Lauridsen, R.B., Kronvang, B., Friberg, N., 2006. Occurrence and impact of sedimentbound pyrethroids in Danish streams and their impact on ecosystem function. Water Air Soil Pollut. 6, 423-432.

Liess, M., Schulz, R., 1999. Linking insecticide contamination and population response in an agricultural stream. Environ. Toxicol. Chem. 18, 1948-1955.

Liess, M., Schulz, R., Liess, M.H.D., Rother, B., Kreuzig, R., 1999. Determination of insecticide contamination in agricultural headwater streams. Water Res. 33, 239-247.

Littell, R.C., Milliken, G.A., Stroup, W.W., Wolfinger, R.D., 1996. SAS ${ }^{\odot}$ System for Mixed Models. SAS Institute Inc., Cary, NC, 633 p.

Marchant, R., 1981. The ecology of Gammarus in running water. In: Lock, M.A. Williams, D.D. (Eds.), Perspectives in Running Water Ecology. Plenum Press, New York, USA, pp. 225-250.

Mathiessen, P., Sheahan, D., Harrisson, R., Kirby, M., Rycroft, R., Turnbull, A., Volkner, V., Williams, R., 1995. Use of a Gammarus pulex bioassay to measure the effects of transient carbofuran runoff from farmland. Ecotoxicol. Environ. Saf. 30, 111-119.

Møhlenberg, F., Kaas, H., Schlüter, L., Gustavson, K., Andersen, T.T., Forbes, V., Cold, A., Friberg, N., Larsen, S.E., Lauridsen, R.B., 2004. Effects of biocides and pesticides on flora and fauna in streams. Bekæmpelsesmiddel-forskning fra Miljøstyrelsen no. 82 (in Danish).

Muirhead-Thomsen, R.C., 1978. Lethal and behavioral impact of permethrin (NRDC 143 ) on selected stream macroinvertebrates. Mosq. News 38, 185-190.

Narahashi, T., Carter, D.B., Frey, J., Ginsburg, K., Hamilton, B.J., Nagata, K., Roy, M.L., Song, J., Tatebayashi, H., 1995. Sodium channels and GABA $A_{A}$ receptor-channel complex as targets of environmental toxicants. Toxicol. Lett. 82/83, 239-245.

Nørum, U., Bjerregaard, P., 2003. Mobility and behaviour of freshwater invertebrates as bio-marker for pesticide exposure and -effect. Bekæmpelsesmiddelforskning fra Miljøstyrelsen no. 75 (in Danish).
Nørum, U., Bjerregaard, P., Larsen, S.E., Friberg, N., 2006. Effects of pulse exposure of pyrethroids on stream invertebrates. Bekæmpelsesmiddelforskning fra Miljøstyrelsen no. 102 (in Danish).

SAS Institute Inc., 1989. SAS/STAT ${ }^{\circledast}$ Users Guide, Version 6, vol. 2, fourth ed. SAS Institute Inc., Cary, NC, $846 \mathrm{p}$.

Schäfer, R.B., Caquet, T., Siimes, K., Mueller, R., Lagadic, L., Liess, M., 2007. Effects of pesticides on community structure and ecosystem functions in agricultura streams of three biogeographical regions in Europe. Sci. Total Environ. 382, 272-285.

Schroer, A.F.W., Belgers, J.D.M., Brock, T.C.M., Matser, A.M., Maund, S.J., Van den Brink, P.J., 2003. Comparison of laboratory single species and field population-leve effects of the pyrethroid insecticide $\lambda$-cyhalothrin on freshwater invertebrates. Arch. Environ. Contam. Toxicol. 46, 324-335.

Schulz, R., Liess, M., 1999a. Validity and ecological relevance of an active in situ bioassay using Gammarus pulex and Limnephilus lunatus. Environ. Toxicol. Chem. $18,2243-2250$.

Schulz, R., Liess, M., 1999b. A field study of the effects of agricultural derived insecticide input on stream macroinvertebrate dynamics. Aquat. Toxicol. 46, 155-1176.

Schulz, R., Hauschild, M., Ebeling, M., Nanko-Drees, J., Wogram, J., Liess, M., 1998. A qualitative field method for monitoring pesticides in the edge-of-filed runoff Chemosphere 36, 3071-3082.

Sibley, P.K., Kaushik, N.K., Kreutzweiser, D.P., 1991. Impact of a pulse application of permethrin on the macroinvertebrate community of a headwater stream. Environ. Pollut. 70, 35-55.

Wallace, J.B., Lugthart, G.J., Cuffney, T.F., Schurr, G.A., 1989. The impact of repeated insecticidal treatments on drift and benthos of a headwater stream. Hydrobiologia 179, 135-147.

Wiggers, L., 1999. Pesticides in Streams, Springs and Lakes in the County of Aarhus. Aarhus Amt, Aarhus, Denmark (in Danish).

Zelinka, M., Marvan, P., 1976. Notes to estimating production of zoobenthos. Folia Fac. Sci. Nat. Univ. Purkynianae Brunensis 17. Biology 58, 1-53. 